\title{
The Effect of Argumentative Text Pattern Teaching on Success of Constituting Argumentative Text Elements
}

\author{
Serpil Özdemir ${ }^{1, *}$ \\ ${ }^{1}$ Faculty of Education, Bartın University, Bartın, Turkey \\ *Correspondence: Faculty of Education, Bartın University, Bartın, 74100, Turkey. Tel: 90-532-470-4271. E-mail: \\ serpilozdemir34@gmail.com
}

Received: August 8, 2018

Accepted: September 1, $2018 \quad$ Online Published: October 12, 2018

doi:10.5430/wje.v8n5p112

URL: https://doi.org/10.5430/wje.v8n5p112

\begin{abstract}
The aim of this study is to view how argumentative text pattern teaching influences constituting argumentative essay elements. The study was performed according to one-group pre-test post-test design. The study was carried out in spring term of 2017-2018 academic year and it lasted for five weeks. 33 prospective teachers who took the course of Text Producing Techniques participated in the study. The data of study were collected through 132 argumentative essays which prospective teachers wrote and Argumentative Text Elements Rubric to evaluate these. The results of the research are as follows: Quite few students included argumentative essay elements before argumentative essay pattern teaching and none of the students wrote justification for counter argument. It was determined that $66,7 \%$ of the students didn't write data, $81,8 \%$ of them didn't write counter argument, $87,9 \%$ did not write justification for counter argument, $84,8 \%$ did not write rebuttal of counter argument and $48,5 \%$ did not write conclusion. At the third study, number of successful students increased on the basis of all elements. However, the majority of students have reached a partially successful level. At the post test, most of the students achieved successful level on the basis of all elements except refuting counter argument. Significant differences on behalf of the post-test were determined between pre-test and post-test scores at all of the argumentative essay elements.
\end{abstract}

Keywords: argumentative text instruction, argumentative text elements, one-group pre-test post-test

\section{Introduction}

\subsection{Introduce the Problem}

Argument is defined as "a reason or reasons why you support or oppose an idea or suggestion, or the process of explaining these reasons" in Cambridge dictionary. In our daily life, we try to solve our problems by discussing about various issues or clarify our views about any issue by observing arguments. Although argument is a part of our life, writing argumentative essay is regarded as a demanding act (Crowhurst, 1990). Argumentative essay is a kind of text in which an author supports his own view and try to refute counter-view about an issue including counter views. The author aims to lead readers to think just like himself in this kind of texts. It is not easy to change readers' view or make them question. The author is expected to explain why he supports these views and why counter-view is invalid so as to achieve his goal. The author is supposed not only to have a strong idea about the issue discussed but also to be wise for a successful argumentative essay (Knudson, 1992).

Argumentative essays present knowledge in a special format unlike narrative and expository essays. In these essays, knowledge is structured through high-level thinking skills which include choosing one option among different options, comparing benefits and drawbacks of the options, presenting the most effective option based on justifications. Since argument can be maintained within different points of view, not only the supported view but also alternative views are presented and refuted and essay is completed which emphasizes the point of view at the beginning. Toulmin's Argument Model (1958) is often used for teaching (Tengberg \& Olin-Scheller, 2016; Qin, 2013) and analyzing (Du, 2017; Lam, Hew \& Chiu, 2018; Midgette \& Haria, 2016) this structure. According to this model, argumentative essays are composed of six elements. Data, claim and warrant are main elements among these. Backing, qualifiers and rebuttal are supportive elements (Toulmin, Reike \& Janik, 1984). In Toulmin's model, data are the main facts on which subject of argument is based. Claim is expression, idea or opinion which represents the 
point of view adopted. The data in argument are supposed to ease understanding of claim. Warrant is the connection through expressions between claim and data. Backings are general conditions supporting acceptability and authority of warrant. Qualifiers present the conditions in which claim is valid. Words such as 'for example, usually, often, absolutely, probably, rarely' state strength of probability of reality. Rebuttals are expressions defining conditions and situations in which claim and warrant are invalid (Toulmin, 1958). A student's creating an argument step by step is possible by means of teaching of argument elements. The first step in writing argument is to present data. Foreknowledges which will help readers make sense of the argument are presented in this section. These knowledges include facts which both sides accept without discussion. In data section, necessary knowledge, in other words problem, is explained so that the argument can be understood better by readers. Thus, author provides a basis for his claim. At the second step, the view author supports, claim, is presented. Claim is also the main idea of the essay. "The claim holds the top position of an argument schema because all other elements of the argument are presented to either support or oppose this main proposition" (Larson, Britt \& Larson, 2004, 206). The third step is to offer justifications for claim backing. Because the author's aim is to persuade, the claim is supported through explanations or proves which reinforce the claim (Nussbaum \& Schraw, 2007). The forth step is to submit counter-claim. Submitting counter-claim is important in that essay is more persuasive (Nussbaum \& Schraw, 2007). While submitting counter-claim, the reason why supported view can be opposed, in other words justification for counter-claim is revealed, too. If counter-claim is acceptable under certain conditions, author can state partial acceptance conditions. Then, why counter-claim and backings of counter-claim are wrong, in other words refuting justification, is submitted and counter-claim is invalidated. Refuting counter-claim is important in terms of approaching readers to the view author supports. By this way, possible objections against the claim in readers' mind are removed. The last step is to complete the essay with a conclusion in accordance with the claim.

It is observed in that students from every age group have trouble in writing argumentative essay in researches which view argumentative essays students have written. Problems about counter-claim draw attention at these researches. Students are observed to tend to disinclude counter-claim (Çakmak, 2013; Felton, Crowell \& Bahşi, 2016; Tiryaki, 2011; Öztürk, 2016) or neglect knowledge which does not support author's view, stating their own claims through one-sided viewpoint (Perkins, Farady \& Bushey, 1991; Toplak \& Stanovich, 2003; Wolfe \& Britt,2008). Including counter arguments functions as "to rebut that view, to increase author credibility, and to minimize the impact of other side points" (Wolfe \& Britt, 2008, 4). Essays written through one-sided point of view are informative rather than persuasive. One of the problems encountered is sequencing backing justifications just like a list instead of explaining them in detail (Crowhurst, 1990). Problems related to data draw attention in researches carried out in Turkey. Coşkun and Tiryaki (2013) stated that $93 \%$ of prospective teachers did not write data and the written data was irrelevant to the argument topic, disorderly and poorly related to the claim. Çakmak (2013) stated that only $12,7 \%$ of prospective teachers wrote data successfully. On the other hand, Öztürk (2016) determined this rate as 10\%. Sis and Bahşi (2016) determined that $81,9 \%$ of 8 th grade students failed in writing data. Teaching argumentative text pattern is not included in Turkish Language Teaching Curriculum (Minister of National Education [MoNE], 2018). As narrative and informative text patterns are included in the curriculum, students compose these patterns more successfully. When they are asked to write argumentative text, they tend to write in patterns they know better. The fact that students fail in coming up with justifications for both their own views and counter-views simultaneously can be regarded as one of the reasons of problems experienced (Nippold \& Ward-Lonergan, 2010). According to Crowhurst (1990), reasons of problems encountered during the process of writing argumentative text are that producing argument is cognitively demanding and students lack a schema for written argument. We are inclined to organize knowledges in forms we are familiar with. Cognitive psychologists explain this situation as schema theory. Schemas are a network of inter-connected ideas, relations and operations in the memory (Slavin, 1986). Information structures acquired in the memory before, in other words schemas are effective in not only comprehending but also producing texts. Studies which search the relation between argumentative reading and writing reveal that those who read this kind of texts constitute a schema related to text pattern in their memories and transfer this schema from reading to writing (Newell et al., 2011). Experimental studies reveal that argumentative text instruction is effective in students' development. Tengberg and Olin-Scheller (2016) stated that students who took the course of recognizing argumentative text elements and analyzing arguments in terms of coherence and sustainability made great progress with regards to determining these in a written text. After argumentative text pattern instruction, the rate of students' inclucion these in their texts increased considerably (Çağlayan Dilber, 2014; Çakmak, 2013; Lam, Hew \& Chiu, 2018; Midgette \& Haria, 2016).

Critical thinking and argumentative writing resemble each other in terms of many ways. According to Willingham (2007) "Critical thinking consists of seeing both sides of an issue, being open to new evidence that disconfirms your 
ideas, reasoning dispassionately, demanding that claims be backed by evidence, deducing and inferring conclusions from available facts, solving problems and so forth". Jamaludin, Caroline and Sun (2007) states that argument can be employed as a mean to teach critical thinking. Çakmak and Civelek (2013) revealed that education of argumentative writing influences students' critical thinking skills in a positive way. Tiryaki (2011) found out a statistically reasonable and positive relation between students' critical thinking skills and writing argumentative text skills. These results show that the argumentative texts develop critical thinking, and it is necessary to think critically on writing this kind of texts as well.

As a result, argumentative writing is a demanding act owing to the necessity of being wise about the issue, structuring knowledge through high-level thinking skills, recognizing argumentative text pattern and presenting thoughts in this pattern. We are supposed to understand or produce this kind of texts in both academic and daily life. It is necessary to recognize this pattern and have experience by writing practices so as to be able to write argumentative text. It is essential that prospective teachers of Turkish language teaching recognize argumentative text pattern and have skills of producing texts in this pattern in that they can gain this skill to their future students. Any study carried out with teachers or prospective teachers of Turkish language teaching hasn't been discovered. That's why, the study is unique. It is anticipated that the results obtained with this study will guide the teacher candidates and teachers in teaching argumentative text.

People's effort to seek truth makes it necessary to look through other views reasonably. Argumentative texts are ground on which people's adventure of finding out truth is written. Turkish Lesson Curriculum accepts improving the skills of regulating, questioning, using and producing knowledge as special aim, however, it does not include learning outcomes related to writing argumentative text for secondary schools (MoNE, 2018). Argument has been a part of our life during the process of adaptation to environment since our childhood. It is inevitable to compose this kind of texts in both academic life and social media. Practices of writing argumentative texts have an important role in that skills of regulating, questioning, using and producing knowledge are improved. Most researches show that few students were able to write argumentative text successfully on their own and they make a great progress by education supplied. Argumentative texts are employed in various disciplines and the most suitable course for teaching argumentative text is Turkish. The better teacher is at this subject, the better student is. Howell et al. (2018) revealed that teachers who took part in writing argumentative text program taught what they learnt to their students and students became more successful. This study was carried out aiming at viewing writing argumentative text skills of prospective teachers studying Turkish language teaching, overcoming the deficiencies, guiding them to solve their problems. In this sense, the problem sentence of the study was determined as "How is the impact of teaching argumentative text pattern on constituting argumentative text elements?" The topic was discussed by these sub-problems:

1. How is prospective teachers' weekly progress in constituting argumentative text elements?

2. Are there significant differences between pre-test and post-test scores of argumentative text elements?

\section{Method}

The study was conducted with a single group pretest-posttest model. In this model, measurements are made before and after experiment in a randomly selected group. If post-test scores are higher than pre-test scores, it is accepted that this results from independent variable (Karasar, 2009). Argumentative text pattern teaching was addressed as the independent variable of study. Since prospective teachers are expected to make progress after this training, any control group wasn't assigned.

\subsection{Study Group}

Study group of the research is comprised of prospective teachers who study at Turkish Language Teaching department at Faculty of Education in Western Black Sea region. 33 prospective teachers, 8 of whom are male and 25 of whom are female, taking the course of Text Producing Techniques participated in the research. The course of Text Producing Techniques was conducted by the researcher. The participants were third-grade students. The study was carried out in spring term of 2017-2018 academic year.

\subsection{Data Collection Tools}

Data of the study were collected through 132 argumentative texts prospective teachers wrote and Argumentative Text Element Rubric (Çağlayan Dilber, 2014) to evaluate these.

In order to determine the topics of argumentative texts which prospective teachers wrote, a list was constituted of 
topics discussed in researches that were conducted before. 15 daily topics which would draw prospective teachers' attention and they could comment on. This list was offered to two experts to receive their opinions. The experts were asked to score each topic by a point between 1 and 5. 10 topics which got 9 and 10 points from the experts were selected. 10 topics that were selected were presented to prospective teachers and they were asked to sign whichever topic they preferred to write. The topics which at least half of the prospective teachers wanted to write and how many people preferred these topics were determined. The prominent topics of the research are as follows:

- Whether interview should be employed in appointment of teachers or not (29 prospective teachers)

- Whether people always should tell the truth or not (26 prospective teachers)

- Whether social media socializes or isolates people (22 prospective teachers)

- Whether money or success makes people happy (21 prospective teachers)

- Whether incurable patients should be bestowed the right of ending their life without pain (euthanasia) or not (18 prospective teachers)

- Whether evaluation based on students' views should be conducted or not while assessing teachers' performance (17 prospective teachers)

In the study, the topic "Whether interview should be employed in appointment of teachers or not" was written at the first week and scores of these texts were used as pre-test. The topic "Whether money or success makes people happy" was used at writing practice with class during the process of argumentative text pattern instruction.

As a text was written on the board with the whole class, it was not included in scoring. The second text written by prospective teachers is "Whether people always should tell the truth or not", and the third text is "Whether social media socializes or isolates people". After three studies, the prospective teachers wrote on a topic they chose on their own, and these texts were evaluated as post-test.

\subsection{Argumentative Text Element Rubric (ATER)}

ATER was developed by Çağlayan Dilber (2014) in order to test functional text elements peculiar to argumentative text type. The elements in rubric are: data, claim, backing justifications, counter-claim, possible justifications for counter-claim, rebuttal of possible justification for counter-claim and conclusion. Rubric is in the form of triple Likert type scale. Rubric consists of short information explaining every element and contents of the scales. 0 point represents absence of the relevant element, 1 point represents partial sufficiency and 2 points represent its sufficiency. The validity of the rubric was ensured by means of specialist view. Students' texts were evaluated separately by two experts in order to test reliability of rubric. Specialist coherence scores are $97 \%$ for data element, $97 \%$ for claim element, $97 \%$ for backing justification element, $94 \%$ for counter-claim element, $100 \%$ for possible justification for counter-claim element, $100 \%$ for rebuttal of possible justifications for counter-claim element, $100 \%$ for conclusion element and $98 \%$ for all elements (Çağlayan Dilber, 2014).

In this study, 16 samples were selected from texts seeming successful and unsuccessful were evaluated by a Turkish Language Teaching specialist so as to test reliability of measurement. Coherence of specialist grades was examined with the researcher. Coherence grade was determined by the process: number of coherent answers / numbers of total answers $\mathrm{x} 100$. It was revealed that coherence grades were $94 \%$ for data, $87 \%$ for claim, $87 \%$ for backing justification, $94 \%$ for counter-claim, $100 \%$ for possible justifications for counter-claim, $100 \%$ for rebuttal of possible justifications for counter-claim, $100 \%$ for conclusion and $95 \%$ for all elements. High level of coherence scores was interpreted as reliability of the measurement. Çağlayan Dilber (2014) was requested permission to use the rubric for this research.

\subsection{Process}

The study was conducted in a-5-week process which includes teaching applications aiming at determining prospective teachers' lacks about the issue and removing these lacks. The actions performed during this process are as follow:

Week 1: Prospective teachers were asked what they knew about argument and argumentative essay and the answers were received verbally. Prospective teachers were informed about the aim and process of the study and it was determined whether they were eager to participate in the study. After prospective teachers were determined to be eager to participate in the study, which topic they wanted to write about was decided. The most wanted topics were determined. They were asked to write an argumentative text about the determined topics without interfering with their knowledge. Argumentative text was written about the topic "Whether interview should be employed in 
appointment of teachers or not?". These texts were used as pre-test data.

Week 2: Argumentative text pattern teaching was practiced. Prospective teachers were informed as to what kind of texts the argumentation could be used in, its importance for improving critical thinking and elements of argumentative text pattern. A sample text was presented on the board and argumentative text elements were examined.

Argumentative text evaluation form was introduced, and the previous week's texts examined according to this form were shared with the prospective teachers. This led them to comprehend which elements they were supposed to develop.

Week 3: A text which included data elements about the topic "Whether money or success makes people happy?" was delivered to the prospective teachers and they were asked to develop claim and counter-claim. The claims and counter-claims developed were listed on the board. A text was composed with propositions selected from the list and participation of the class. While composing the text, prospective teachers' opinions about justification for claim backings, justification for counter-claim backings, partial acceptance of counter-claim and rebuttal of counter-claim were received. A conclusion based on the claim and counter-claim was written with the class and the text was completed.

After that, the topic "Whether people always should tell the truth or not?" was brainstormed and prospective teachers were asked to write argumentative text about this topic. The written texts were exchanged between peers. They were requested to determine argumentative text elements and score by means of evaluation form. The purpose was to raise prospective teachers' awareness about argumentative text elements by means of peer evaluation.

Week 4: The previous week's texts evaluated by the researcher based on rubric were shared with prospective teachers. They were ensured to recognize which elements they were supposed to develop. In this view, it was revealed that the prospective teachers concentrated on main elements of argumentative text and failed in progress at supporting elements. Moreover, on the topic "Whether evaluation based on students' views should be conducted or not while assessing teachers' performance" a text was written with the participation of the whole class which defends the topic unilaterally. Then, backing justification for counter-view was included and propositions were determined so as to refute them. The selected propositions were added to the text and it was completed by this way. This study aimed at leading students to notice persuasiveness of the texts which include counter-claims. Next, a schema, consisting of five paragraphs, which reveals opinion organization in an argumentative text was written on the board. The purpose was to enable students to notice how they could organize their own views and the views they opposed to by means of this schema. A big and blank paper was drawn on the board and a symbolic pattern was formed.

After the template was created, prospective teachers were asked to write this template on papers they were delivered. After brainstorming about "Whether social media socializes or isolates people?", argumentative text was written on this topic. On this text argument elements were determined and scored through peer evaluation.

Week 5: The previous week's texts were evaluated by the researcher. Positive developments about data, claim, justification for backing claim and conclusion elements drew attention within this evaluation. However, it was revealed that prospective teachers still lack of counter-claim, justification for backing counter-claim and rebuttal of counter-claim elements. These determinations were shared with prospective teachers and their views about the reasons of problem were received. Prospective teachers stated that although they knew argumentative text pattern, the reasons of problems were being unprepared for the topic, writing in a limited time and sometimes failing in finding something to write about the topic which majority of the class had chosen. As a solution, it was decided that students were supposed to write about a topic they chose and send it to the researcher by e-mail before the lesson of following week so that the researcher could evaluate them. According to the review conducted, the study which was carried out without limiting class hour and having opportunities for research led most of the prospective teachers to write texts including argumentative text elements. These texts which prospective teachers wrote about any theme in a week were used as post-test data of the study. The study results were shared with prospective teachers and the study was completed.

\subsection{Analysis of Data}

Descriptive analysis was applied to determine weekly progress of prospective teachers' composing argumentative text. Paired sample t-test was applied in order to determine whether there was a significant difference between pre-test and post-test scores. As it was revealed that the data were not ranged normally, Wilcoxon Signed Rank Test was used. 


\section{Results}

The first sub-problem of the research is aimed at determining how the weekly progress of prospective teachers' composing text elements is. Frequency analysis that was conducted based on ATER is revealed at Table 1.

Table 1. Weekly Progress in Composing Argumentative Text Elements

\begin{tabular}{|c|c|c|c|c|c|c|c|c|c|}
\hline & \multirow[t]{2}{*}{$\begin{array}{l}\text { Success } \\
\text { Level }\end{array}$} & \multicolumn{2}{|c|}{$\begin{array}{l}1^{\text {st }} \text { Text } \\
\text { (Pre-test) }\end{array}$} & \multicolumn{2}{|c|}{$2^{\text {nd }}$ Text } & \multicolumn{2}{|c|}{$3^{\text {rd }}$ Text } & \multicolumn{2}{|c|}{$\begin{array}{l}4^{\text {th }} \text { Text } \\
\text { (Post-test) }\end{array}$} \\
\hline & & $\mathbf{f}$ & $\%$ & $\mathbf{f}$ & $\%$ & $\mathbf{f}$ & $\%$ & $\mathbf{f}$ & $\%$ \\
\hline \multirow[t]{3}{*}{ Data } & Absent & 22 & 66,7 & 19 & 57,6 & 10 & 30,3 & 1 & 3,0 \\
\hline & Partly successful & 10 & 30,3 & 7 & 21,2 & 13 & 39,4 & 12 & 36,4 \\
\hline & Successful & 1 & 3,0 & 7 & 21,2 & 10 & 30,3 & 20 & 60,6 \\
\hline \multirow[t]{3}{*}{ Claim } & Absent & 6 & 18,2 & 1 & 3,0 & 0 & 0 & 0 & 0 \\
\hline & Partly successful & 25 & 75,8 & 25 & 75,8 & 18 & 54,5 & 1 & 3,0 \\
\hline & Successful & 2 & 6,1 & 7 & 21,2 & 15 & 45,5 & 32 & 97,0 \\
\hline \multirow[t]{3}{*}{ Justification for backing } & Absent & 4 & 12,1 & 3 & 9,1 & 0 & 0 & 0 & 0 \\
\hline & Partly successful & 25 & 75,8 & 22 & 66,7 & 22 & 66,7 & 2 & 6,1 \\
\hline & Successful & 4 & 12,1 & 8 & 24,2 & 11 & 33,3 & 31 & 93,9 \\
\hline \multirow[t]{3}{*}{ Counter-claim } & Absent & 27 & 81,8 & 13 & 39,4 & 9 & 27,3 & 1 & 3,0 \\
\hline & Partly successful & 5 & 15,2 & 17 & 51,5 & 17 & 51,5 & 8 & 24,2 \\
\hline & Successful & 1 & 3,0 & 3 & 9,1 & 7 & 21,2 & 24 & 72,7 \\
\hline \multirow[t]{3}{*}{ Justification for counter-claim } & Absent & 29 & 87,9 & 18 & 54,5 & 9 & 27,3 & 1 & 3,0 \\
\hline & Partly successful & 4 & 12,1 & 15 & 45,5 & 18 & 54,5 & 11 & 33,3 \\
\hline & Successful & 0 & 0 & 0 & 0 & 6 & 18,2 & 21 & 63,6 \\
\hline \multirow[t]{3}{*}{ Rebuttal of counter-claim } & Absent & 28 & 84,8 & 19 & 57,6 & 11 & 33,3 & 4 & 12,1 \\
\hline & Partly successful & 3 & 9,1 & 14 & 42,4 & 19 & 57,6 & 15 & 45,5 \\
\hline & Successful & 2 & 6,1 & 0 & 0 & 3 & 9,1 & 14 & 42,4 \\
\hline \multirow[t]{3}{*}{ Conclusion } & Absent & 16 & 48,5 & 5 & 15,2 & 4 & 12,1 & 0 & 0 \\
\hline & Partly successful & 14 & 42,4 & 22 & 66,7 & 22 & 66,7 & 9 & 27,3 \\
\hline & Successful & 3 & 9,1 & 6 & 18,2 & 7 & 21,2 & 24 & 72,7 \\
\hline
\end{tabular}

As can be seen at Table 1, quite few students include argumentative text elements at the first study. There is not any student who wrote justification for counter-claim. $66,7 \%$ of students did not write data. $81,8 \%$ did not include counter-claim, $87,9 \%$ did not include justification for counter-claim, $84,8 \%$ did not include rebuttal of counter-claim and $48,5 \%$ did not include conclusion.

There is no student who is good at justification for counter-claim and rebuttal of counter-claim at the second writing practice. Number of successful students began to increase at all the other elements. However, there are some students who did not include argumentative text elements. $57,6 \%$ of the students did not include data, $39,4 \%$ did not include counter-claim, 54,5\% did not include justification for counter-claim, 57,6\% did not include rebuttal of counter-claim and $15,2 \%$ did not include conclusion.

At the third writing practice, all the students included justification for claim and backing. However, it draws attention that $30,3 \%$ of students did not write any data. Number of successful students increased based on all elements. Majority of the students are partly successful.

At the forth writing practice, all students included claim, justification for backing claim and conclusion elements. Most of the students became successful at elements of data (60,6\%), claim (97\%), justification for backing claim $(93,9 \%)$, counter-claim $(72,7 \%)$, justification for counter-claim $(63,6 \%)$ and conclusion $(72,7 \%) .12,1 \%$ of the students did not include rebuttal of counter-claim. Rate of successful students of this element $(42,4 \%)$ is lower than all the other elements.

The weekly averages of prospective teachers' success in creating argumentative text elements were viewed. The weekly averages of success are revealed at Table 2 . 
Table 2. Weekly Averages of Success in Creating Argumentative Text Elements

\begin{tabular}{llllll}
\hline \multicolumn{1}{c}{ Argumentative Text Elements } & N & Pre-test & & & Post-test \\
\hline 1. Data & 33 &, 36 &, 64 & 1,00 & 1,58 \\
2. Claim & 33 &, 88 & 1,18 & 1,45 & 1,97 \\
3. Justification for backing & 33 & 1,00 & 1,15 & 1,33 & 1,94 \\
4. Counter-claim & 33 &, 21 &, 70 &, 94 & 1,70 \\
5. Justification for counter-claim & 33 &, 12 &, 45 &, 91 & 1,61 \\
6. Rebuttal of counter-claim & 33 &, 21 &, 42 &, 76 & 1,30 \\
7. Conclusion & 33 &, 61 & 1,03 & 1,09 & 1,73 \\
\hline
\end{tabular}

For each element, 0 represents insufficiency, 1 represents partial sufficiency and 2 represents sufficiency. At table 2 , in the texts written before argumentative text pattern teaching, it is noticed that prospective teachers are partly good at justification for backing claim and they fail in all the other elements. After argumentative text pattern teaching, there was a progress at all elements. At the second and third practices, data, claim, justification for backing claim and conclusion elements reached to partial sufficiency level. However, success at data, counter-claim, justification for counter-claim, rebuttal of counter-claim elements maintained remaining under partial sufficiency level. At the forth writing practice, success at all elements except rebuttal of counter-claim approached to sufficiency level. Rebuttal of counter-claim (mean=1,30) is the least progressed element. When the progress of success in weekly averages of argumentative text elements is viewed, the result can be noticed more clearly. The chart is revealed at figure 1.

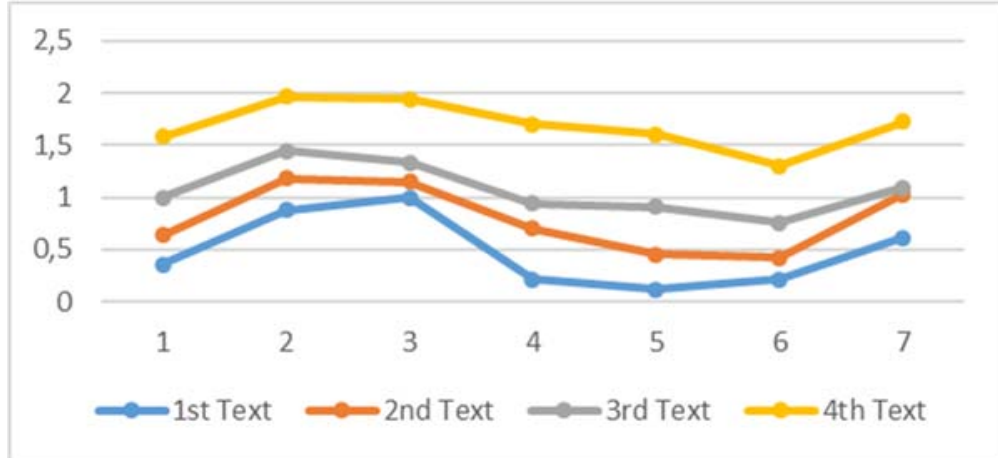

Figure 1. Weekly Progress of Argumentative Text Elements

As can be inferred from image 2, before argumentative text pattern teaching, the elements at which students are best are claim and justification for backing claim. The elements in which they fail most are the ones related to counter-claim. The weekly progress is increasing in accordance with the beginning level.

The second sub-problem is aimed at determining whether there are significant differences between pre-test and post-test scores of argumentative text elements success or not. T-test which was performed for this reason can be seen at Table 3.

As seen in Table 3, there are significant differences between pre-test and post-test scores in all argumentative text elements. After argumentative text pattern teaching, there is not any student who got lower score than pre-test in terms of using argumentative text elements. 5 students at data, 3 students at claim, 6 students at justification for support, 3 students at counter-claim, 8 students at rebuttal of counter-claim and 8 students at conclusion remained on the same level at both pre-test and post-test. 33 students participated in the research. Considering the positive order, it is clearly noticed that using argumentative text elements of the participant improved between $76 \%$ and $91 \%$. 
Table 3. Pre-test and Post-Test Difference of Argumentative Text Elements

\begin{tabular}{|c|c|c|c|c|c|c|}
\hline & & $\mathbf{N}$ & $\begin{array}{l}\text { Mean } \\
\text { Rank }\end{array}$ & $\begin{array}{l}\text { Sum of } \\
\text { Ranks }\end{array}$ & $\mathbf{z}$ & $\mathbf{p}$ \\
\hline \multirow[t]{3}{*}{$\overline{\text { Data }}$} & Negative Ranks & 0 & ,00 & 00 & 4,774 &, 000 \\
\hline & Positive Ranks & 28 & 14,50 & 406,00 & & \\
\hline & Ties & 5 & & & & \\
\hline \multirow[t]{3}{*}{ Claim } & Negative Ranks & 0 & ,00 &, 00 & 5,108 &, 000 \\
\hline & Positive Ranks & 30 & 15,50 & 465,00 & & \\
\hline & Ties & 3 & & & & \\
\hline \multirow[t]{3}{*}{ Justification for backing } & Negative Ranks & 0 &, 00 &, 00 & 4,916 &, 000 \\
\hline & Positive Ranks & 27 & 14,00 & 378,00 & & \\
\hline & Ties & 6 & & & & \\
\hline \multirow[t]{3}{*}{ Counter-claim } & Negative Ranks & 0 &, 00 & ,00 & 4,964 &, 000 \\
\hline & Positive Ranks & 30 & 15,50 & 465,00 & & \\
\hline & Ties & 3 & & & & \\
\hline \multirow[t]{3}{*}{ Justification for counter-claim } & Negative Ranks & 0 &, 00 & ,00 & 5,023 &, 000 \\
\hline & Positive Ranks & 31 & 16,00 & 496,00 & & \\
\hline & Ties & 2 & & & & \\
\hline \multirow[t]{3}{*}{ Rebuttal of counter-claim } & Negative Ranks & 0 &, 00 &, 00 & 4,512 &, 000 \\
\hline & Positive Ranks & 25 & 13,00 & 325,00 & & \\
\hline & Ties & 8 & & & & \\
\hline \multirow[t]{3}{*}{ Conclusion } & Negative Ranks & 0 & ,00 &, 00 & 4,507 &, 000 \\
\hline & Positive Ranks & 25 & 13,00 & 325,00 & & \\
\hline & Ties & 8 & & & & \\
\hline
\end{tabular}

\section{Discussion}

This study was conducted with the purpose of determining how argumentative text pattern teaching influences success of composing argumentative text elements. It was revealed that number of students who included argumentative text elements was quite few before education. It was stated that none of the students wrote justification for counter-claim. $66,7 \%$ of the students did not write data, $81,8 \%$ did not include counter-claim, $87,9 \%$ did not include justification for counter-claim, $84,8 \%$ did not include rebuttal of counter-claim and 48,5\% did not include conclusion. It was noticed that students were relatively better at elements associated with claim.

Similar results are noticed at researches carried out by means of scanning pattern. Coşkun and Tiryaki (2013) stated that half of the students did not present any data and include counter-claim, a considerable number of them did not present justification for counter-claim and they failed in writing conclusion. The elements at which students are best are the ones related to the claim. According to the researches relevant to this issue, students are better at claim element (Coşkun \& Tiryaki, 2013; Du, 2017; Öztürk, 2016; Perkins et al., 1991). Students' being better at claim element can be associated with the fact that they have more words to write about the view they support. However, when argumentation is built on opposite views, it can lead readers to question and maybe change their views. After all, the purpose of argumentative narration is to "prove, persuade, convince, evidence, introduce, reveal, defend a point of view, lead readers to think just like himself by writing in such a way, make readers admit his own view" (Günay, 2007, 324). There are several reasons why students care about claim and do not include counter-claim: "Students' lack of understanding about the value of argument-counter argument structure in making their essays more persuasive" (Du, 2017,126), the belief that including counter-argument will make the claim weak, having weak, underdeveloped or faulty argument schema (Wolfe \& Britt, 2008) can be accepted among these reasons. Larson et al., (2004) wanted university students to find out claim and reasons by making them read argumentative texts. Only $30 \%$ of the students were able to find out these elements correctly. While students' finding out argumentative elements even in written texts is demanding, it is cognitively more demanding to constitute these elements by themselves. One of the reasons of problems experienced is that students do not have enough knowledge and experience about 
argumentative text pattern. At this point, argumentative text pattern teaching gains importance.

All students failed in submitting justification for counter-claim and rebuttal of justification for counter-claim at the first study after argumentative text pattern teaching. Number of successful students began to increase in all the other elements, however, $57,6 \%$ of the students did not include data, 39,4\% did not include counter-claim, 54,5\% did not include justification for counter-claim, 57,6\% did not include rebuttal of counter-claim and $15,2 \%$ did not include conclusion. It was observed that prospective teachers concentrated on main elements of argumentative text and did not make much progress in supporting elements. In order to lead students to notice persuasiveness of including counter-claim at argumentative text, a practice of composing a text which defends an opinion unilaterally was conducted. After that, the text was completed by adding counter-argument, justification for backing and propositions to refute these. A five-paragraph argumentative text schema was drawn on the board and the students were shown how they could arrange the views they support and the ones they oppose.

After the teaching, every student included claim and justification for backing at the third writing practice. However, $30,3 \%$ of the students did not write data at this study, either. Number of successful students increased in all elements. Moreover, majority of the students reached the level of partly successful. Before the forth writing practice, the students were interviewed with and the source of problem was determined. It was revealed that students had difficulty in finding out word to write about a topic which was chosen by the majority of class in a limited time. Therefore, students were asked to write about a topic they chose on their own in a week. In this way, students had more opportunities to search and think about the topic. At the forth writing practice, all students included claim, justification for claim backings and conclusion elements. Most of the students were successful at data $(60,6 \%)$, claim (97\%), justification for claim backings $(93,9)$, counter-claim $(72,7 \%)$, justification for counter-claim $(63,6 \%)$, and conclusion $(72,7 \%)$ elements. This success may be associated with ongoing writing practices and argumentative text pattern teaching as well as writing out of the classroom in a week. The element which has the least rise is rebuttal of counter-claim among all elements. However, given the success in rebuttal of counter-claim rose from 0 to $42,4 \%$, it can be regarded as a great rise. It is commonly noticed in the researches that success is low at elements related to counter-claim. Du (2017) revealed that half of university students did not write counter arguments and rebuttal. Perkins et al., (1991) stated that university students tend to not write any counter-argument.

Although students included counter- argument in this study, they did not emphasize why that view was wrong. The students showed a position that accepts both views. In fact, refuting counter-argument through justification increases persuasiveness of the argument (Nussbaum \& Schraw, 2007). After the teaching progress related to argumentative essay pattern, students' still disincluding rebuttal of counter-argument can be explained with their having superficial knowledge and lack of critical thinking skills. Critical thinking training has a positive impact on students' argumentative essay writing skills (Khunaifi, 2015). That's why, developing critical thinking skills before argumentative essay writing practices is regarded as essential to eliminate the problems experienced during the process of writing counter-argument.

Success in weekly rise of composing argumentative text elements continued in parallel with the level of the first week. This result reveals the importance of students' previous knowledge and skills. When pre-test and post-test scores were compared, significant differences at all elements were determined on behalf of post-test. Conducting argumentative text pattern teaching theoretically and practically, determining students' development needs and planning teaching to meet these needs led students to have a cognitive schema related to this pattern. The texts students wrote were evaluated by both the researcher and peers so as to evaluate this pattern by means of rubric. The feedbacks based on the criterion contributed to prospective teachers' development considerably.

\subsection{Suggestions}

It is suggested that studies aimed at developing critical thinking skills should be conducted before studies of writing argumentative essay in order to raise success of writing argumentative essay.

Argumentative essay has a special format. Students' being able to express their opinions in accordance with this format is possible via argumentative text pattern teaching. While planning teaching of this pattern, a hierarchic teaching plan is required in that argumentative text pattern is adopted. Informing about argumentative text pattern and reviewing on examples by teacher at the first stage, making students read argumentative texts and wanting them to review which will enable them to determine argumentative text elements at the second stage, leading them to develop argument and counter-arguments in groups by presenting an essay of which data part was written at the third stage, doing individual writing practices in class by brainstorming about a topic at the fourth stage can be included in the plan. On the other hand, since the students do not search about topic and think enough during writing practices conducted in the class, they cannot write qualified argumentative texts. The last stage of teaching argumentative text 
pattern should be planned in a way they can write independently.

Evaluating through a rubric peculiar to the essay pattern and giving feedback regularly have a significant contribution to students' understanding what is expected from them. That's why, it is important to present the evaluation criterion to the students at the beginning of the study and give feedback after each writing practice.

Writing argumentative text includes deciding, critical thinking and problem-solving skills. Although developing these skills are aimed at education programs, it is not included in curriculum of Turkish lesson. Argumentative essays are employed in the selective course of authorship and writing skills for secondary schools. Writing opinions in a certain order is an act every student who gets training can manage. Limiting argumentative writing in a selective course means that some students will not be able to progress in this term. Argumentative writing is included in the course of Turkish Language 1 at bachelor's level program of Turkish Language Teaching. Besides, argumentative writing as one of many theoretical knowledges which will be provided in Writing Education is included. Argumentative writing teaching should be included in secondary education and higher education curriculums more comprehensively.

\section{References}

Coşkun, E., \& Tiryaki, E. N. (2013). Problems of university students on constituting the structure of argumentative text. Adiyaman University Journal of Social Sciences, 6(11), 101-141.

Crowhurst, M. (1990). Teaching and learning the writing of persuasive/argumentative discourse, Canadian Journal of Education, 15(4), 348-359. https://doi.org/10.2307/1495109

Çağlayan Dilber, N. (2014). The effect of self-regulated strategy development model on secondary school students' argumentative texts. Unpublished doctoral dissertation. Ankara University, Ankara.

Çakmak, E. (2013). The effect of teaching argumentative writing on teacher candidates' argumentative writing skills. Journal of Theory and Practice in Education, 9(4), 379-389.

Çakmak, E., \& Civelek, F. (2013). The effect of argumentative writing instruction on critical thinking tendency and writing anxiety of pre-service teachers. Gazi University Journal of Gazi Educational Faculty, 33(2), 355-371.

Du, F. (2017). The analysis of argument-counterargument structure in Chinese EFL learners' argumentative writing. Journal of Studies in Education, 7(3), 121-129. https://doi.org/10.5296/jse.v7i3.11275

Felton, M., Crowell, A., \& Liu, T. (2015). Arguing to agree: Mitigating my-side bias through consensus-seeking dialogue. Written Communication, 32(3), 317-331. https://doi.org/10.1177/0741088315590788

Günay, V. D. (2007). Metin bilgisi. İstanbul: Multilingual Yayınları.

Howell, E., Hunt-Barron, S., Kaminski, R., \& Sanders, R. (2018). Teaching argumentative writing to teachers and students: Effects of professional development. Professional Development in Education, 44(2), 169-189, https://doi.org/10.1080/19415257.2016.1272478

Jamaludin, A., Caroline, H. M. L., \& San, C. Y. (2007). The impact of structured argumentation and enactive role play on students' argumentative writing skills. In ICT: Providing choices for learners and learning. Proceedings ascilite Singapore, 430-432.

Karasar, N. (2009). Bilimsel araştırma yöntemi. (20th Ed.) Ankara: Nobel Yayın Dağıtım.

Khunaifi, A. R. (2015). The effects of teaching critical thinking on students' argumentative essay. Journal on English as a Foreign Language, 5(1), 45-55. http://dx.doi.org/10.23971/jefl.v5i1.91

Knudson, R. E. (1992). The development of writing argumentation: An analysis and comparison of argumentative writing at for grade levels. Child Study Journal, 22(3), 167-184.

Lam, Y. W., Hew, K. F., \& Chiu, K. F. (2018). Improving argumentative writing: Effects of a blended learning approach and gamification. Language Learning \& Technology, 22(1), 97-118. https://doi.org/10125/44583

Larson, M., Britt, A., \& Larson, A. A. (2004). Disfluencies in comprehending argumentative texts. Reading Pshcology, 25(3), 205-224.

Midgette, E., \& Haria, P. (2016). Planning and revising written arguments: the effects of two text structure-based interventions on persuasiveness of 8th-grade students' essays. Reading Psychology, 37, 1043-1075. https://doi.org/10.1080/02702711.2016.1159631 
MoNE. (2018). Türkçe dersi ögrretim programı, Ankara.

Newell, G.E., Beach, R., Smith, J., VanDerHeide, J., Kuhn, D., \& Andriessen, J. (2011). Teaching and learning argumentative reading and writing: A review of research. Reading Research Quarterly, 46(3), 273-304. https://doi.org/10.1598/RRQ.46.3.4

Nippold, M., \& Ward-Lonergan, J. (2010). Argumentative writing in pre-adolescents: The role of verbal reasoning. Child Language Teaching and Therapy, 23(3), 238-248. https://doi.org/10.1177\%2F0265659009349979

Nussbaum, M. E., \& Schraw, G. (2007). Promoting argument-counter argument integration in students' writing. The Journal of Experimental Education, 76(61), 59-92. https://doi.org/10.3200/JEXE.76.1.59-92

Öztürk, D. (2016). A research on argumentative text writing skills of teacher candidates. Unpublished Master's Thesis. Inonu University, Malatya, Turkey.

Perkins, D., Farady, M., \& Bushey, B. (1991). Everyday reasoning and the roots of intelligence. In: Voss, J.F., Perkins, D.N., Segal, J.W. (Eds.), Informational Reasoning and Education. Erlbaum, Hillsdale, NJ, 83-106.

Sis, N., \& Bahşi, N. (2016). An investigation on the argumentative text writing skills of eighth grade students. Turkish Studies International Periodical for the Languages, Literature and History of Turkish or Turkic, 11(3), 2025-2042. http://dx.doi.org/10.7827/TurkishStudies.9450

Slavin, R. E. (1986). Educational psychology: Theory into practice. Englewood Cliffs, New Jersey: Prentice Hall.

Tengberg, M., \& Olin-Scheller, C. (2016). Developing critical reading of argumentative text: Effects of a comprehension strategy intervention. Journal of Language Teaching and Research, 7(4), 635-645, http://dx.doi.org/10.17507/jltr.0704.02

Tiryaki, E. N. (2011). University students' skills of writing argumentative text and writing anxiety and critical thinking skills. Unpublished Master's Thesis. Mustafa Kemal University, Hatay, Turkey.

Toplak, M. E., \& Stanovich, K. E. (2003). Associations between myside bias on an informal reasoning task and amount of post-secondary education. Applied Cognitive Psychology, 17, 851-860. https://doi.org/10.1002/acp.915

Toulmin, S. (1958). The uses of argument. Cambridge, UK: Cambridge University Press.

Toulmin, S., Rieke, R., \& Janik, A. (1984). An introduction to reasoning. New York NY: Macmillan.

Willingham, D. T. (2007). Critical thinking why is it so hard to teach? American Educator, Summer 2007, 8-19. https://doi.org/10.3200/AEPR.109.4.21-32

Wolfe, C. R., \& Britt, M. A. (2008). The locus of the myside bias in written argumentation. Thinking \& Reasoning, 14, 1-27. https://doi.org/10.1080/13546780701527674 